\title{
Government and Agency Response to Soil Erosion Risk in Europe
}

\author{
Michael A Fullen, ${ }^{1}$ Andres Arnalds, ${ }^{2}$ Paolo Bazzoffi, ${ }^{3}$ Colin A Booth, ${ }^{1}$ Victor Castillo, ${ }^{4}$ \\ Ádám Kertész, ${ }^{5}$ Philippe Martin, ${ }^{6}$ Coen Ritsema, ${ }^{7}$ Albert Solé Benet, ${ }^{8}$ \\ Véronique Souchère, ${ }^{6}$ Liesbeth Vandekerckhove ${ }^{9}$ and Gert Verstraeten ${ }^{10}$ \\ ${ }^{1}$ School of Applied Sciences, University of Wolverhampton, Wolverhampton WV1 1SB, UK \\ ${ }^{2}$ Soil Conservation Service, Gunnarsholt, 851 Hella, Iceland \\ ${ }^{3}$ Experimental Institute for Soil Study and Conservation, Piazza D'Azeglio 30, Firenze, Italy \\ ${ }^{4}$ Centro de Edafología y Biología, Aplicada del Segura, Campus Universitario de Espinardo, \\ Murcia, Spain \\ ${ }^{5}$ Geographical Research Institute, Hungarian Academy of Sciences, Budaörsi út 45, H-1112 \\ Budapest, Hungary \\ ${ }^{6}$ UMR SAD APT INRA INAPG, BP 1, 78850 Thiverval Grignon, France \\ ${ }^{7}$ ALTERRA, Soil Science Centre, PO Box 47, 6700 AC Wageningen, The Netherlands \\ ${ }^{8}$ Estacion Experimental de Zonas Aridas (CSIC), General Segura 1, 04001 Almeria, Spain \\ ${ }^{9}$ Ministry of Flanders (Land Division), Wetstraat 34-36, 1040 Brussels, Belgium \\ ${ }^{10}$ Physical and Regional Geography Research Group, Katholieke Universiteit Leuven, \\ GEO-INSTITUTE, Celestijnenlaan 200 E, 3001 Heverlee, Belgium
}

\subsubsection{INTRODUCTION}

\footnotetext{
'The dust is gold that bears the harvest; Save the soil that grows our bread; Let not wind and rain remove it; Guard with care for years ahead.'
} 
Soil conservation in Europe has not generally received sufficient attention, until recently. However, a picture has gradually emerged, largely developed by individual research teams from various academic institutions. In Northern Europe, the Katholieke Universiteit Leuven (Belgium) has made a particular contribution. Erosion surveys were often conducted by Quaternary geologists and geomorphologists, who increasingly viewed evidence of agriculturally induced erosion in their landscapes (Fullen, 2000, 2003).

Faced with evidence of increased frequency and severity of soil erosion, a considered approach to soil conservation is essential. This must take into account both the common attributes and diversity of European agronomic, environmental and social conditions. The soil conservation policies of 10 European countries (Belgium, Denmark, France, Germany, Hungary, Iceland, Italy, The Netherlands, Spain and the UK) are reviewed. These countries were selected as representative of European regions (i.e. north, east, west and Mediterranean Europe, plus Scandinavia). The soil conservation policies are compared with several Australian and US strategies and several policy instruments recommended as appropriate approaches to soil conservation throughout Europe.

\subsubsection{REVIEW OF EUROPEAN NATIONAL POLICIES}

\subsubsection{Belgium}

Individual regions of Belgium are responsible for their own environmental issues; thus soil conservation policies differ between the Flanders and Wallonia regions. For instance, soil degradation has been recognised as an environmental problem for more than a decade in Flanders, resulting in the conception and implementation of the Flemish Environmental Action Plan (1997-2001). In contrast, policy developments have not yet been observed in Wallonia. Although several agri-environmental measures (e.g. cover crops and grass buffer strips along rivers and field boundaries) are implemented by many farmers experiencing erosion problems, none were originally meant to control erosion as part of regional policy (Bielders et al., 2003).

The latest Flemish Environmental Action Plan (2003-07) recognizes erosion as a threat to long-term soil sustainability and addresses soil protection through erosion control. In December 2001, the Flemish Government issued a decree concerning 'the subsidy of small-scale erosion control measures to be taken by local authorities', often called the 'Soil Erosion Decree'. This Decree regulates subsidies to municipalities on two levels. First, municipalities dealing with erosion problems in the hilly regions of Flanders are stimulated to draw up a municipal soil erosion action plan, indicating their proposed measures. The Flemish Government provides municipalities with $€ 12.5 \mathrm{ha}^{-1}$ of plan area. Once the Land Division of the Flemish Administration (AMINAL, Land) approves a plan, it grants a $75 \%$ subsidy for the implementation of approved measures. The measures are selected from a 'Code of Good Practice - Erosion Control', currently being prepared by the Flemish Administration, and will include mostly small-scale technical control methods, such as the construction of small dams, sedimentation ponds, grass buffer strips and grassed waterways. Soil conservation measures carried out by farmers, such as conservation tillage or cover crops, are not subsidised via the 'Erosion Decree', but can be recommended in a municipal soil erosion action plan. However, for other environmental reasons, farmers can be subsidised annually for sowing cover crops during autumn ( $€ 50 \mathrm{ha}^{-1}$ ) and for sowing grass strips with a width of 5-10 $\mathrm{m}$ along rivers and sunken lanes ( $€ 0.13 \mathrm{~m}^{-2}$ ). These practices are now also promoted within the framework of the soil erosion control policy. Other subsidies for farmers, relevant for soil erosion prevention, include subsidies for afforestation (between $€ 850 \mathrm{ha}^{-1}$ for poplar and $€ 3700 \mathrm{ha}^{-1}$ for oak) and set-aside (€298-424 ha ${ }^{-1}$, depending on agricultural region and crop type). Further grants for agricultural practices which decrease soil erosion are expected to be available in 2004, through the 'Flemish Plan for Rural Development', within the framework of European Directives. These measures will 
include soil conservation actions at the field scale and were approved by the European Commission (EC) in August 2003.

Establishment of a municipal soil erosion action plan occurs in close cooperation with farmers and this participatory approach has been applied recently in many Flemish demonstration projects (Verstraeten et al., 2003). Only when farmers are fully involved in project design and dissemination can new conservation techniques be successfully implemented on a broader scale. To assist municipalities in establishing a soil erosion action plan, the Flemish Government subsidises them for organising awareness raising actions such as erosion-prevention demonstration fields ( $€ 125$ per field), for excursions with farmers to an erosion prevention project (€250), for advisory courses (€50 per session) and to approach individual farmers in order to put the proposed actions into practice (€50 per farmer).

Flemish policy makers use several soil erosion indicators (Vandekerckhove et al., 2003). The most important indicator is the soil erosion risk map of Flanders, based on the application of the RUSLE with 20-m resolution and aggregated at the field scale (Van Rompaey et al., 2000). Furthermore, long-term effects of soil erosion on soil fertility are evaluated for each field, using soil profile information from the 1:20 000 Belgian Soil Map. Effectiveness of conservation measures is estimated by modelling decreased soil loss at the field scale and decreased sediment delivery to rivers, using a spatially distributed soil erosion and sediment delivery model (Verstraeten et al., 2002). The Walloon government is keen to establish a soil erosion control policy soon, embracing the Flemish model.

\subsubsection{Denmark}

Denmark has low erosion rates compared with areas of southern Europe (European Environment Agency, 2000), yet there is a very active programme of soil conservation, particularly in terms of coastal wind erosion control (Als, 1989). This was initiated during the 19th century, when Hedeselskabet (the Danish Land Development Service) provided free plants to establish windbreaks to address serious erosion problems. Regional shelterbelt projects can cover $50 \%$ of expenses for soil preparation, plants, planting and hedge maintenance for 3 years. Despite the high investment costs, this policy resulted in the planting of $1000 \mathrm{~km}$ of shelterbelts per year (Veihe et al., 2003). Today, Hedeselskabet continues to offer technical support for establishing windbreaks, but government subsidies are available for the purchase of certified plants. The success of these schemes is attributed to farmer participation and good products, plus government involvement, by actioning a specific windbreak law in 1976, which has been revised several times (Veihe et al., 2003).

Tillage erosion rates are relatively high in Denmark, at an estimated average of $\sim 6 \mathrm{tha}^{-1}$ (Heckrath, 2000). The Foulum Research Centre started a 3-year EU-funded project (FAIR3) in 1997, with the aim of quantifying tillage erosion, determining its effect on soil fertility and investigating the influence of farming practices on soil erosion and quality (Djurhuus and Heckrath, 2000). Yet there still remains no law dealing specifically with tillage erosion (Veihe et al., 2003).

In 1986, the Danish Nature Council and the national media publicly highlighted eutrophication problems, which, supported by the Agricultural Council, forced the government to inaugurate the Water Environment Protection Plan I (WWPP I) and the NPo (nitrogen, phosphorus and organic matter) research programme. However, policy measures to address water erosion are initiated through the designation of 'Specifically Vulnerable Agricultural Areas' (SVAA). Government subsidy measures include set-aside, 2-m wide buffer strips around all watercourses in rural areas and use of rye-grass catch crops (Sibbesen and Iversen, 1997). WWPP I was superseded in 1998 by the Water Environment Protection Plan II (WWPP II), after erosion control became recognised as a mechanism for reducing agrochemical contamination.

It has been argued that the Danish Land Development Service (Hedeselskabet) could act as a general organisational model for Europe (Morgan and Rickson, 1990), as they operate an integrated approach to landscape management (Dubgaard, 2000). However, a change of government in late 2001, associated with 
major environmental sector cut-backs, has been accompanied by an attempt to simplify laws to ameliorate working conditions and increase profit within the agricultural sector. This is instigated by the notion that farmers are best placed to formulate their own decisions regarding farming practices and concomitant environmental effects (Veihe et al., 2003).

\subsubsection{France}

Many areas of France have a long history of soil erosion problems. For instance, in mountainous areas a state organisation (Mountain Land Restoration of the National Office of Forests) has been responsible for soil protection for over a century (Lilin, 1986). Elsewhere, in the Bourgogne vineyards, 19th century private contracts forced farmers to retrieve and replace eroded soil (Durousset, 1994). In rural areas, no specific contracts or laws were applied to soil protection and a national survey in 1950 revealed soil erosion in mountainous areas had been alleviated and insignificant erosion problems existed on farmlands (Hénin and Gobillot, 1950). This situation prevailed until the 1970s.

The first French agricultural law (1960), preceding the first common agricultural policy (1962), led to conversion of grasslands to cereals and field enlargement (Vivier et al., 1985). Increases in runoff and muddy floods have also been linked to post-War urbanization. These storm events often had disastrous and sometimes fatal consequences and caused increased infrastructure damage. A proposed solution was a natural disaster law (1982), aimed at providing compensation for the victims of natural disasters, but this failed to address the source of the problem.

There continues to be no specific legislation on soil protection in France, because soil erosion is an unrecognised problem for and by farmers. Moreover, widespread chemical use or irrigation systems are considered to balance negative impacts of soil erosion on agricultural production. Instead of soil protection, water (quality and quantity) is viewed as the principal national environmental issue. However, water policies have some positive effects on erosion control. The Water Law (1992) initiated the division of France according to the six main catchment areas and established the foundations of the coordinated and sustainable development of water resources. The Water Law significantly increased the role and responsibilities of local authorities, reinforced regulations and provided new tools (Schéma Directeur d'Aménagement et de Gestion des Eaux, SDAGE). In this new framework, the designation of protected areas around catchments ensured the compulsory reintroduction of permanent grassland and helped local stakeholders manage problems at the catchment scale instead of at the water resource (i.e. river, lake) level. The framework considerably assists in dealing with erosion issues. At the same time, the Common Agricultural Policy (CAP) reforms (European Regulation No. 2078/92) introduced some positive agri-environmental measures for erosion control, mostly those concerning both protection and extension of grassland. Measures for extensification of livestock help to maintain grassland in highland areas. Other long-term (i.e. 20 years or longer) measures included set-aside of agricultural land (payment $€ 457 \mathrm{ha}^{-1}$ ) and the reversion of arable land to extensive grassland (payment $€ 381 \mathrm{ha}^{-1}$ ). However, in areas of intensive agriculture, these measures were unattractive. For instance, Upper Normandy gave a supplement of $€ 76 \mathrm{ha}^{-1}$ to encourage the reversion of arable land to extensive grassland for 5 years. In this erosion prevention instrument, grasslands must be located in thalwegs. Farmers received subsidies corresponding to the long-term set-aside of agricultural land without being required to commit themselves for 20 years. In 1999, the French farm framework law No. 99-574 introduced 'Territorial Exploitation Contracts' (CTEs) to establish rural development projects that addressed environmental, economic and social issues. Access to agri-environmental measures became conditional on agreeing to a CTE. Depending on local needs, some CTE have focused on erosion control, but difficulties in implementation and high cost led to the halt of CTE measures. In 2001, CTEs were replaced by a new contract ('Contrat d'Agriculture Durable', CAD), which is more economical since it only considers environmental issues. 
Despite the lack of national soil protection legislation, local public authorities became aware that erosion control involves coordination (Cartier, 2002). Consequently, some authorities formulated plans to solve environmental problems, notably erosion. For example, recent erosion problems in Seine-Maritime led to the designation of 'Syndicats de bassin versants' (hereafter referred to as the Syndicates), corresponding to the main catchment areas. In accordance with the State-Region Plan, Water Authorities control the steering committee of Syndicates. Syndicates recruit advisors, with hydraulic or agricultural abilities, charged with implementing hydraulic solutions and encouraging farmers to change agricultural practices.

At the local level, it became evident that both hydraulic and agricultural solutions to soil erosion problems were necessary. However, modifying agricultural practices is difficult, for three reasons. First, farmers' decisions are strongly influenced by technological and commercial considerations and economic support under CAP, plus changes in crop management systems have fuelled environmental uncertainties (Souchère et al., 2003). Second, the diversity of natural conditions (e.g. climate, soils), crops and agricultural practices causes difficulties in establishing and adapting technical guidelines for agricultural practices suitable for these different conditions (Papy et al., 1996; Martin et al., 2004). Finally, since agricultural extension services are directly financed by farmers' taxes to advise farmers how to increase their net income, soil erosion was not viewed as a farming problem until recently. The main reason is that agricultural advisors experienced difficulties in estimating the efficiency of new cultivation techniques and also their economic consequences (Cattan and Mermet, 1998). Furthermore, the incentive for advisors to promote change fails when agricultural prices decline, because their own funding is reduced. In future, it is hoped that local communities may subsidise agricultural extension services to contribute to the development of adapted technical guidelines, in cooperation with the National Agronomy Research Institute (INRA).

\subsubsection{Germany}

In Germany, soil conservation legislation has recently been developed, with the main stress on conserving water quality (Weingarten and Frohberg, 2000). For instance, some soil conservation requirements were incorporated into the state law of the German Lande of Baden-Württemberg in 1991 (Jäger, 1994). Now, over 30 Federal laws and regulations govern environmental protection. The Federal Soil Protection Act (Act on Protection Against Harmful Changes to Soil and on Rehabilitation of Contaminated Sites) became Federal Law on 1 March 1999 (Frielinghaus, 2001). The purposes of the Act are to protect and restore soil functions on a permanent and sustainable basis and to concentrate on both precautions and hazard protection. The latter is achieved by the provision of a code of good management practice, dealing especially with risks of soil erosion and compaction. Good farming practice includes designing appropriate treatments with regard to the site and climatic conditions, maintaining and improving soil structure, promoting biological activity and protecting soil humus from deterioration. The Act provides a useful model for European soil protection legislation and is being consulted in the design of legal instruments in other European countries (e.g. Belgium and the UK).

\subsubsection{Hungary}

Soil erosion is a major soil degradation process in Hungary (Várallyay, 1989; Kertész 2001). Soil protection legislation includes many forms of soil degradation, such as soil erosion, salinity, extreme acidity and soil pollution. Before the political regime change of 1989, Hungarian agriculture was highly subsidised, making it one of the most successful branches of the national economy, with high crop yields and a good reputation, which was exceptional among the former socialist countries.

Soil conservation legislation is enshrined in Chapter VI of Hungarian State Law No. 55 (1994), in which soil conservation is considered a joint task between the State and the land user. The State develops national soil conservation policies, ascribes to international agreements and provides farmers and planners with information 
systems on soil quality, in the form of maps, soil data and legal, economic and technical instruments. A soil conservation service has been initiated ('Service for Plant Protection and Soil Conservation'), comprised of a national network of plant health and soil conservation stations, with one in each of the 19 Hungarian counties.

Land users are obliged to conserve topsoil and its organic matter content and to conduct environmentally friendly farm management. This is achieved by appropriate land use, cultivation technology and soil conservation measures. Law 55 includes actions for eroded and erodible soils, including land-use regulations, provision of protective vegetal cover and cultivation methods. If these measures cannot guarantee good protection against erosion, a conservation plan must be formulated, specifying appropriate actions.

After the regime change, a complicated reprivatisation process started, resulting in a very complex land ownership structure. Some cooperative farms ceased to exist, while some remained with changes to their legal status and many new private farms were established. These were diverse, in terms of both size and financial viability. Consequently, most new farms are facing challenging economic positions, so soil conservation is given low priority, which is a recurrent problem in the other former socialist countries.

Law 55 stresses that both land users and the State are important partners in soil protection. It is imperative to learn farmers' opinions on soil erosion and conservation. According to a case study of 44 farmers in Keszthely, near Lake Balaton, two-thirds of farmers would not spend money on erosion control, even if they had the resources (Puskás, 2002). However, approximately the same proportion of questioned farmers were convinced about the damaging effect of erosion and $40 \%$ of them considered soil loss due to erosion was very high. Some $50 \%$ of the farmers did apply soil conservation measures and only $25 \%$ remained passive and did not take any conservation action.

Joining the EU in 2004 will certainly change both agricultural policy and the attitude of farmers in all Accession States. The EU strategy on soil conservation will influence the national policies of these countries, hopefully in a positive direction.

\subsubsection{Iceland}

The severity of soil erosion in Iceland prompted the creation of Northern Europe's only designated soil conservation service, the Landgraedsla Rikisins (SCS), in 1907 (Runolfsson, 1978; Arnalds, 2000). The first 50 years were mainly devoted to halting sand dune encroachment and other forms of catastrophic soil erosion that were threatening several settlements. The Forestry Service, originally established by the same law as the SCS, had the role of combating woodland destruction and promoting reforestation. It is possible to identify several attributes of successful practice from the almost 100 years of combating ecosystem degeneration and desertification in Iceland.

About half of the vegetation and $95 \%$ of woodland cover has been lost in the 1100 years of settlement, and the condition of the remaining vegetation is severely degraded in many areas. Serious soil erosion characterises $40 \%$ of Iceland according to a national survey completed in 1997 (Arnalds et al., 2001). This survey represents a major breakthrough, as increasingly, people accept the reality of erosion problems and focus on their solution.

Since 1990, there has been an increasing participatory approach to soil conservation, which has markedly increased the adoption and success of conservation projects (Arnalds, 1999). The 'Farmer's Reclaim the Land' Project (Arnalds, 2000) includes a 'cost-share' partnership with farmers, with conservation work jointly funded by government and farmers. This 'bottom-up' approach encourages involvement and individual ownership of conservation projects. The rapidly increasing forestry in Iceland, which also has a large role in land improvements, has a strong farmer and public participation focus.

Current developments include a Parliament-approved programme, which gives the SCS an operational framework for the period 2003-14, with increased funding. The main goals are mitigation of land degradation and desertification, revegetation of eroded land and attaining sustainable land use. Tools include increased 
knowledge on problems and solutions, education and advice, land-user responsibility, legal improvements and widening participation. Carbon sequestration as a tool in meeting Iceland's obligations under the Kyoto Protocol has also become a major incentive for restoring land health (Arnalds, 2004).

Grazing by sheep and horses is a major determinant of land health in Iceland. In the heavily subsidised sheep industry (with $\geq 50 \%$ of farmers' income being subsidised), the current contract between sheep producers and government has a cross-compliance clause that, starting in 2003-04, farmers must verify the ecological sustainability of their operation to the Landgraedsla Rikisins in order to obtain a full subsidy (Arnalds and Barkarson, 2003). In the important horse production sector, a voluntary 'bottom-up' quality control of sustainability is emerging. A new cooperative programme of farm planning, 'Better farms' combines the forces of soil conservation, forestry, extension and nature conservation in aiding land users in producing their own property plans. This is a very promising programme, which not only brings farmers into the planning process, but also improves coordination between the various institutions and organizations working with farmers. Icelandic soil conservation systems have been presented as an organizational model generally within Europe (Morgan and Rickson, 1990; Boardman et al., 2003).

\subsubsection{Italy}

Soil erosion plays an important role in Italian land degradation and the European Soil Bureau estimates that $\sim 70 \%$ is at risk of accelerated erosion, defined as erosion $>5 \mathrm{t} \mathrm{ha}^{-1} \mathrm{yr}^{-1}$ (Grimm et al., 2002). These risks relate to the widespread presence of steep erodible slopes, combined with intensive cultivation and lack of conservation measures.

National legislation considers soil conservation the result of public actions for soil stability and hydraulic security applied to soil, subsoil, water, urban areas and infrastructures. Italian Law 183 (18 May 1989) on 'soil defence' identifies a hydrological basin as the operating context for soil conservation planning. Each hydrological basin is defined by the law as a 'unitary ecosystem', i.e. a complex environment with its own homogeneity, where coordination and harmonisation of several functions related to soil conservation can be implemented, along with water management.

Establishment of the 'Basin Authorities', at national, regional and interregional levels, is one of the major innovations brought about by soil conservation reform. They assume responsibility for the territorial coordination of all the functions carried out by the State, regions and provinces with reference to matters listed in the law and this is accomplished mainly through 'Basin plans'. These include responsibility for soil stabilisation by both agrarian and forest hydraulic conservation structures, protection and consolidation of slopes against landslides and avalanches and prevention of both soil subsidence and seawater intrusion into aquifers and rivers.

Significant progress was made in soil conservation in 1999, when the 'Code of good agricultural policy' was approved by the Ministry of Agricultural and Forestry Policies. This contains national standards and directions that can be incorporated by regions and provinces to suit local requirements. The Code was approved under Article 4 of Directive 91/676/EC of the Council (12 December 1991) and implemented EC Regulation 1257/99. This regulation calls for agri-environmental measures to finance those actions extending beyond normal 'Good Agricultural Practice' (GAPn). Regions have defined GAPn to suit different local requirements and have developed detailed plans to decrease soil erosion risk (particularly decreasing soil tillage and mouldboard ploughing and promoting crop rotations that ensure soil cover during rainy seasons). As a result, farmers implementing CAP agri-environmental measures are given subsidies.

Other important legislation tools for soil conservation are Law 97 (1994) and the National Programme to Combat Drought and Desertification (NAP) (1999). Law 97 determines conditions necessary to enhance soil protection in mountain areas, through the development of farming activities that avoid soil erosion and maintain the landscape and natural resources. NAP encourages Regions and Basin Authorities to identify 
'areas vulnerable to desertification' and 'remedial criteria', which includes the prevention and remediation of soil erosion and salinisation, slope protection through low-impact environmental actions, fire prevention and the adoption of farming, livestock and forestry management systems aimed at preventing the physical, chemical and biological degradation of soil.

Of the $€ 146.26$ million committed to implement NAP, $30 \%$ is devoted to soil protection actions, $15 \%$ to reducing the impact of industrial activities and $20 \%$ to restoring soil equilibrium. NAP measures will continue to be adopted through existing funding instruments, such as rural development, water protection and river basin management plans, forest and afforestation programmes, EU Structural funds (2000-06) and CAP measures.

\subsubsection{The Netherlands}

During recent decades, soil protection legislation has primarily focused on prevention and remediation of soil contamination. The National Soil Protection Act (1987) provided the framework for establishing rules relating to categories of activities hazardous to soil. In addition, there are provincial environmental policy plans devoted to the protection of potable groundwater. Consequently, areas have been designated around extraction points within which activities hazardous to the soil require particular care. Furthermore, local authority environmental policy plans are in force and address specific soil protection issues. Additionally, agreements have been defined and formalised with several branches of industry, including agriculture, to limit the burden on the environment, and soil in particular. For instance, some soil conservation requirements have been incorporated by a ruling from the Dutch Agricultural Board (Landbouwschap) in 1992 (Boardman et al., 1994). Soil conservation organisational structures are developing in South Limburg, where a coordinated soil conservation project was conducted in the 1990s (Duijsings, 1994). The Limburg Soil Conservation Project (Erosienormeringsprojekt) involves active collaboration between government (provincial and municipality), agricultural advisory services, university research institutes and local farmers. Demonstration projects and information dissemination are important components of the programme (Boardman et al., 1994; de Roo et al., 1995). The soil conservation approach followed in the Limburg Soil Conservation Project has been applied elsewhere in The Netherlands, for instance in defining best conservation strategies for the erosion-prone area of Groesbeek in the eastern Netherlands (Stolte and Ritsema, 2001; Stolte et al., 2002). Both the Limburg and Groesbeek Projects may well act as future models for European soil conservation policy.

Various national Ministries and related organisations have recently acknowledged that soil legislation and regulations are too narrowly focused and not harmonised with existing national and international environmental acts. Hence legislation should be reviewed, to make it more transparent and acceptable to the public, and more easily applicable and manageable for the respective authorities. In 2002, the Ministry of Housing, Spatial Planning and the Environment (VROM) established a Steering Committee 'Soil' (Stubo), in which other Ministries, provinces and municipalities participate in preparing a National Integrated Soil Policy Framework. This new policy should address soil protection in the widest sense, integrating the entire spectrum of soil physical, chemical and biological functions and properties. Through this process, soil conservation and runoff and erosion processes may receive appropriate governmental and agency responses.

\subsubsection{Spain}

Erosion has long been recognized in Spain (Mallada, 1890), but targeted research did not start until the second half of the 20th century (see Chapter 1.26), with the creation of the 'Servicio Central de Conservación de Suelos' (Central Service of Soil Conservation) in 1955. However, since adoption of the 1978 Constitution, Spain has become less centralized, comprising of 17 Autonomous Regional Governments with many responsibilities, including erosion control. Many soil erosion and conservation issues are administered by 
different institutions within the Ministry of the Environment (Dirección General de Conservación de la Naturaleza, DGCN), formerly ICONA, and the 10 Basin Authorities (Confederaciones Hidrográficas).

Autonomous governments and national research institutions [e.g. CSIC, 'Consejo Superior de Investigaciones Científicas' (High Research Council for Scientific Research), and CEDEX ('Centro de Estudios y Experimentación de Obras Públicas', Centre for Experimental Studies of Public Works)] and universities have been the primary contributors to erosion research over the two last decades. In 1981, ICONA, in collaboration with CSIC and several universities, established the ongoing LUCDEME (Lucha contra la desertificación en el Mediterráneo) Project, to combat desertification in Mediterranean basins. Since then, maps of actual and potential soil erosion have been produced. Derived from LUCDEME, in 1995, RESEL [Red de Estaciones de Evaluación y Seguimiento de la Erosión y la Desertificación en España (Network of Experimental Stations for Assessing and Monitoring Soil Erosion and Desertification in Spain)] was established. The Project investigates erosion in problematic environments using field sites, at plot, hillslope and small catchment scales (Rojo and Sanchez-Fuster, 1997).

The National Research and Development Plan is the basic instrument for Spanish research policy and includes two National Programmes dealing directly with the causes, consequences and control of both desertification and soil erosion. For the last 20 years, soil erosion research has been conducted and funded by both national and European institutions. The EC has also given priority to large erosion research projects, such as DESERTLINKS, MEDACTION, MEDALUS, GEORANGE and PESERA.

Spanish agricultural policy, since joining the EC, has been dominated by the CAP, whose priority is the development of sustainable and ecologically sound agriculture. However, CAP implementation in southern Mediterranean European countries, and particularly in Spain, has had contradictory effects on soil erosion (e.g. set-aside resulted in a dramatic increase in the extent of bare soils vulnerable to erosion). CAP reforms, in the context of Agenda 2000, signified a new era of integrated development of rural areas, including soil protection and erosion control. Satisfying the new goals of the CAP, Agenda 2000 proposed related changes in the market-oriented agricultural and rural development policies.

A major development of compensatory payments is an option for countries to make direct payments, subject to compliance with environmental standards (EC1259/99). The Spanish eco-conditionality principle, adopted by Royal Decree 1322/2002, includes soil conservation practices for protecting fallow land from erosion, avoidance of stubble burning and prohibition of tillage on steep slopes.

Rural Development Policy Regulation 1257/99 provides funding from the European Agricultural Guidance and Guarantee Fund (EAGGF) to establish new development rural plans for Good Farming Practices (GFP). The Code of Good Farming Practices was approved by National Decree 4/2001 (13 January 2001). It contains valid national standards for tillage, alternate crops and the use of fertilizers among other aspects. These standards could be modified by regional governments to suit local requirements. Application of agri-environmental measures, regulated by National Decrees (4/2001 and 708/2002), pursue programmes of environmentally friendly agricultural soil protection practices. However, until recently, lack of coordination and co-finances meant bureaucratic delays in these programmes. Actual funded agri-environmental measures (€378.26 million over the period 1995-99) were less than the estimated mean annual cost of $€ 258.4$ million [Ministerio de Agricultura, Pesca y Alimentación (MAPA), 2000]. Since then, public investment of $€ 1207$ million (with an EU contribution of $€ 827$ million) million) has been committed for funding agri-environmental measures for 2000-06. Accompanying CAP measures are also scheduled and national funding committed.

A further instrument of policy development is the afforestation of agricultural lands, regulated by Royal Decree 6/2001, which substitutes former legislation of Regulation 2079/92, and establishes an Aid Programme for the afforestation of former agricultural lands. Its main objective is to increase the income of farmers affected by EU policies, by promoting forestry as an alternative use, to enhance long-term forest resources and to combat soil erosion and desertification (Gomez-Jover, 1996). In this case, programme implementation is the 
responsibility of the Autonomous Communities, but is also co-financed by the central administration and the EU (EAGFF).

Since its creation in 1901, the Hydrology and Forest Divisions have been responsible for Spanish forest administration and have considerable experience in protecting soil against water erosion and rehabilitating degraded vegetal cover. Since their creation, most responsibility for forest resources and nature conservation has been transferred to autonomous communities. However, central government [through the General Directorate for Nature Conservation (DGCN) of the Ministry of the Environment] coordinates plans and programmes related to soil protection and desertification control. This includes the Spanish Forestry Strategy (EFE), the National Forest Plan (NFP) and the Autonomous Forest Plan. Objectives include the design of new forestry policies, emphasising multiple use of forests; organisation of forest resource responsibilities within the central administration, coordination with autonomous administrations and renewal of forest activity as a means of generating employment and economic activity.

The Forestry Strategy, developed by the NFP, promotes reforestation of degraded plant cover areas, wildfire protection and application of silvicultural treatments to improve forest quality [Ministerio de Medio Ambiente (MIMAM), 2001]. The Strategy foresees the reforestation of $3.8 \times 10^{6}$ ha affected by soil losses $>5 \mathrm{tha}^{-1} \mathrm{yr}^{-1}$ and the construction of $6.9 \times 10^{6} \mathrm{~m}^{3}$ of control structures to stabilize torrential water courses. To address the application of programmes and actions to control soil erosion and combat desertification the NFP includes the 'National Plan of Prioritized Actions to Hydrological and Forest Restoration, Soil Erosion Control and Combating Desertification'.

Thirteen Autonomous Communities have drafted documents on forest policy and forestry master plans, of which seven have promulgated regional forest resource laws. Most plans identify the restoration of degraded lands affected by soil erosion, by the means of revegetation, and the need for sustainable forestry to control soil erosion and its off-site effects. For instance, the Forest Law of Valencia (Ley Forestal de la Comunidad Valenciana 3/93) highlights the fight against desertification, prevention of forest fires, restoration of vegetable cover and flood protection as major objectives. Thus, a reforestation plan was implemented for 1994-99. The plan foresaw re-vegetation of 100,000 ha of public lands, with a budget of $€ 160$ million.

The 'National Plan of Prioritized Actions to Hydrological and Forest Restoration, Soil Erosion Control and Combating Desertification' promoted by DGCN in 1991 (Rojo, 1998) aims to control soil erosion and establish locations and priorities for land rehabilitation in degraded river basins, according to both the use of river basins as operational units and soil erosion severity. Hydrological and forest restoration activities developed under 'Cooperation Conventions with Autonomous Government' (1997-2001) shows that the Plan is failing its initial goals.

In the future, 'The National Plan of Hydrological Forest Restoration and Erosion Control' will be integrated in the National Actions Programme to Combat Desertification (NAPD). When Spain became a signatory to the UN Convention to Combat Desertification (CCD) in 1996, it was committed to establishing an NAPD. This is being prepared by a working party group coordinated by DGCONA, with the main objective of sustainable development in Spain's arid, semi-arid and dry subhumid areas and, particularly, the prevention and reduction of land degradation, the rehabilitation of partly degraded land and reclamation of desertified areas.

In 2002, DGCN initiated a national inventory of soil erosion (INES), which aims to locate, quantify and analyse the evolution of erosion processes in Spain. The main objectives are to prioritise target areas for soil conservation and define and evaluate national plans on reforestation, plant cover improvement and the management of forest biodiversity. In every province an inventory and map (1:50 000 scale) will be made of rill, gully, river bank and wind erosion and mass movements. Inventory maps have been completed for the provinces of Madrid, Murcia and Lugo, five more are at an advanced stage and another five are in progress. The inventory will cover all 50 provinces and will take about 10 years to complete. The inventory will then be repeated on a cyclical basis. 


\subsubsection{The UK}

There is increasing evidence in the UK that soil erosion poses at least a moderate to severe problem at local to regional scales (Boardman and Evans, 1994), although government involvement remains only moderate. In the 1980s, the Agricultural Development and Advisory Service (ADAS), then a constituent part of the Ministry of Agriculture, Fisheries and Food (MAFF), published two advisory bulletins to help farmers minimize erosion (ADAS, 1984, 1985). Since then, a 'Code of Good Agricultural Practice for the Protection of Soil' has also been published (MAFF, 1993) and a detailed guide to soil conservation for farmers (MAFF, 1999). The Environment Agency (formerly the National Rivers Authority) was established on 1 April 1996, with a remit to protect the UK environment, including its soils. It is likely the Environment Agency will play a significant role in soil conservation (Boardman, 2002).

Several relatively simple approaches would reduce national soil erosion. MAFF recognised that set-aside schemes may contribute to soil conservation (MAFF, 1991, 1994, 1999; Margach, 1993) and, furthermore, grassland protection of riparian zones would decrease sediment delivery to streams and rivers (Morgan, 1992). The MAFF (1999) booklets advised farmers on simple techniques to produce a farm-size soil erosion risk map and approaches to combat erosion on areas 'at risk'. Particular emphasis was placed on grass strips on arable slopes and buffer strips in riparian zones. Grass strips were recommended to be $5-15 \mathrm{~m}$ wide and every $50-150 \mathrm{~m}$ downslope, with the width of the strip increasing and the gap between strips decreasing as erosion risk increased.

An independent, government-sponsored report advised the government to devise and implement a soil protection policy (Royal Commission, 1996). An outcome of the report was the preparation of a 'Draft Soil Strategy for England - a Consultation Paper' in March 2001 [Department of the Environment, Transport and the Regions (DETR), 2001]. Following public consultation, in which interested members of the public were invited to comment on the draft, the Strategy is being prepared for approval by the UK Parliament. By comparison, the nature and scope of the Strategy is similar to the German 'Federal Soil Protection Act (1999)'. In the more federal government structure, recently adopted in the UK, the legislation will be specifically for England, although legislation will be forwarded to the separate regional assemblies of Scotland, Wales and Northern Ireland. Although this will facilitate legislation fine-tuned to local conditions, it will inevitably slow the process of implementation, as fundamentally similar legislation will be subject to ratification by four separate legislative assemblies. The draft strategy is available at: http://www.defra.gov.uk/environment/ consult/dss/.

Progress has been made, with the submission of two reports. Stirling University (Scotland) reported to the Scottish Executive, recommending a soil protection strategy for Scotland (Adderley et al., 2001). The Centre for Ecology and Hydrology (Bangor, Wales) has presented a similar strategy to the Welsh Assembly. The respective texts are available at http://www.envsci.stir.ac.uk/spstrategy/index.htm and http://www.bangor. ceh.ac.uk/English/science/reports.htm.

Agri-environment schemes in the UK, directed by MAFF [renamed the Department for Environment, Food and Rural Affairs (DEFR) in 2001], aim to secure environmental benefits above those of Good Farming Practice and cross-compliance conditions. Introduced in 1987 to implement EU Council Regulation 797/85, they were designed to prevent loss of habitat and landscape features associated with intensification at sites targeted by the Environmentally Sensitive Areas (ESA) Scheme. Subsequently, in 1991, the Countryside Steward Scheme (CSS) was established to provide incentives to landowners, farmers and other land managers to take specific measures to conserve, enhance and/or recreate important landscape types. In 1994, the Habitat Scheme (HS) was initiated to create, protect and enhance wildlife habitats by removing land from agricultural production and promoting environmentally sound land management practices. In 1995, the Moorland Scheme (MS) was launched with the objective of protecting and improving the upland moorland environment. In 1998, the Arable Stewardship Pilot 
Scheme (ASPS) was created to assess alternative arable management options for conserving and enhancing farmland biodiversity (Ecoscope Applied Ecologists, 2003). In December 2003, the UK government initiated a new agri-environment initiative, known as the 'Environmental Stewardship Scheme' (ESS). The scheme operates two-tier participation. The 'Lower Entry Level Scheme' encourages farmers to deliver simple, yet effective, environmental land management, which will help to diffuse pollution, prevent loss of biodiversity and landscape character and damage to the historic environment. The 'Higher Level Scheme', launched in 2005, is based on the existing CSS and ESAs. Its five main objectives are wildlife conservation; protection of the historic environment; maintenance and enhancement of landscape quality and character; promoting public access; and understanding and resource protection (http://www.defra.gov.uk/erdp/ reviews/agrienv/default.htm).

DEFRA is drafting 'The First Soil Action Plan for England 2004-06'. The plan has the overarching principle to 'ensure that England's soils will be protected and managed to optimise the varied functions that soils perform for society, in keeping with the principles of sustainable development and on the basis of sound evidence' (draft 7 November 2003).

\subsubsection{REVIEW OF RELEVANT NATIONAL POLICIES BEYOND EUROPE}

\subsubsection{Australia}

The Australian Landcare system offers a possible model for group participation in soil conservation. Landcare began in Victoria in 1986 and has grown to encompass $25 \%$ of the farming community (Campbell, 1995). Landcare adopts an integrated and holistic approach to resource sustainability and is a cooperative venture between Federal and State governments, extension services, consultants and farmers (Curtis and DeLacy, 1995). Over 2700 Landcare groups cooperate on local land degradation issues, which are usually managed at the catchment scale (Hannam, 2000). Issues addressed include identification of land degradation problems and implementation of solutions, development of demonstration sites and promotion of community and stewardship (Ewing, 2000). Education is especially important, in particular, encouragement of 'land literacy' among participants (Campbell, 1995). The scheme has also been successfully adopted in New Zealand (Ministry for the Environment of New Zealand, 1996; Bettjeman, 2000). Some have added cautionary notes over the adoption of Landcare schemes, including the need to maintain fundamental research capabilities (Hannam, 2000) and avoidance of over-optimism on the potential success of the scheme (Bradsen, 2000).

\subsubsection{North America}

In North America, soil erosion research and conservation has been established since the 1930s. A great deal of experience has been accumulated and, consequently, many North American policies, lessons and perspectives have direct relevance to the formulation of European soil conservation policies (Boardman, 1991). In the European context, it should be noted, US and Canadian systems are well structured to deal with erosion policies at national, regional and local levels. Policies are in place, which are largely advisory, but incorporate elements of coercion.

North American soil conservation was galvanised by the severe erosion of the 'Dust Bowl' of the US Great Plains States during the 'dirty thirties' (Bagley, 1979; Hurt 1981). The US Soil Erosion Service, founded in 1933, renamed the Soil Conservation Service (SCS) in 1935, is a permanent branch of the US Department of Agriculture (USDA) (Soil Conservation Society of America, 1980). The US SCS [renamed the National Resources Conservation Service (NRCS) in 1994] remains the principal authority responsible for soil 
conservation, with over 13000 employees, and is directly under the jurisdiction of the Secretary for Agriculture. The Soil Survey Division of NRCS provides local and regional soil maps, essential for the formulation of soil conservation strategies. At the NRCS National Soil Survey Laboratory in Lincoln, NE, the Soil Survey Division also analyses samples collected by the staff of around 1000 scientists, thus ensuring accurate and comparable data.

To administer NRCS policies, soil conservation districts are established, usually adopting County boundaries (the administrative subunit of the State). Each district has a conservationist, who is responsible for providing local soil conservation advice. Every district also possesses a 'Board of Supervisors', consisting of unpaid citizens who share an interest in soil conservation. There are 2950 conservation districts, covering most of the $171 \times 10^{6}$ ha of US cropland (Steiner, 1990). Each State appoints a State conservationist, responsible to the NRCS headquarters in Washington, DC.

The NRCS adopts a voluntary land-use planning approach to soil conservation, termed the information, education and subsidy' approach (Napier and Napier, 2000a). Upon request by farmers, a conservationist will recommend appropriate strategies for reducing soil erosion to acceptable levels. The NRCS does not possess mandatory powers of land control, but non-implementation of conservation policies can exclude farmers from Federal and State grant-aided programmes. The Conservation Title of the Food Security Act (1985) and the Food, Agriculture, Conservation and Trade Act (1990) introduced elements of coercion into soil conservation policies (Napier, 1990; Esseks and Kraft, 1991). 'Sodbuster provisions' deny farmers access to farm programme benefits if they crop 'highly erodible land' (HEL) without an approved soil conservation plan. 'Swampbuster provisions' aim to prevent conversion of wetland to crop production, while the 'Conservation Reserve Program' (CRP) attempts to retire highly erodible land from agricultural production. The 'Conservation Compliance Provisions' have the greatest potential for long-term reductions in erosion. According to legislation, operators of HEL had to develop an officially approved plan by 1 January 1990, with full implementation by 1 January 1995. Non-compliance resulted in the loss of all USDA farm benefits until an approved plan was implemented (Napier, 1990). The Federal Agricultural Improvement and Reform Act (1996), or FAIRA, increased the emphasis on conservation in current food security legislation (Napier and Napier, 2000a; Weber and Margheim, 2000).

Much can be learnt from North American strategies and policies, but they would need modifying and adapting to European conditions. For instance, set-aside policies were borrowed from North America and established to reduce European grain surpluses (Marsh, 1987; Clarke, 1992; Jones, 1992). However, it is feasible that steep to moderate slopes with erodible soils and other vulnerable parts of fields (i.e. depressions, minor dry valleys and land adjacent to water courses) be put to set-aside (Boardman, 1988; Fullen, 1991a; Chambers and Garwood, 2000). This policy was successfully adopted in the 'Permanent Cover Program' in the Canadian Prairies (Vaisey et al., 2000). Preliminary evidence from both the South Downs of England (R Eevans and J Boardman, personal communication, 1996) and Shropshire, England (Fullen, 1998) suggests temporary set-aside and permanent grassland are very effective for soil and water conservation. A 'more directed policy' has been proposed in the UK by the Royal Commission on Environmental Protection, which recommended 'the government make maximum use of national discretion to adopt environmental and soil protection criteria in the selection of land for set-aside, and encourage this approach to set-aside at EU level' (Royal Commission, 1996; Recommendation 24).

The impact of set-aside on soil erosion and its off-site consequences is not straightforward, as demonstrated by a modelling exercise for cultivated catchments in central Belgium (Verstraeten et al., 2002). For regions with different soil, land-use and morphological characteristics, the impact of the same set-aside percentage results in different erosion rates. Furthermore, decreases in off-site sediment delivery may be different from decreases in soil loss, depending on the location and environment of set-aside fields. Sites prone to soil erosion are not necessarily those fields delivering most sediment to river channels. The optimal location of set-aside fields will therefore depend on policy goals. 
In a 50-year review of US soil conservation experience, Sanders (1990) argued that policies must be developed, based on thorough analysis and understanding of the problems, and they should remedy causes of erosion, rather than simply treating symptoms.

\subsubsection{SYNTHESIS OF NATIONAL POLICIES: TOWARDS A SOIL CONSERVATION POLICY FOR EUROPE}

Successes and failures of various policies developed in the industrialised world (Australia, Europe and North America) were debated at an international conference in Prague in 1996. Based on these discussions, Napier et al. (2000a) presented 38 chapters, which thoroughly explore these issues.

Voluntary and non-government organisations have an important role in developing soil conservation policy (Schnepf, 2000). Development of informed debate is critical to future development of European soil conservation and several organisational developments are assisting. The European Society for Soil Conservation (ESSC) was founded in November 1989, with the mission of developing an integrated European approach to issues of soil erosion and conservation. The ESSC consists of a group of scientists attempting to influence governmental policies and public attitudes towards erosion problems (http:// www.zalf.de/essc/essc.htm). It consists of 534 members from 46 countries, including 36 European countries (Valencia Congress, March 2000). The initial ESSC Conference, in Coventry in 1990, resulted in a valuable overview of European research (Boardman et al., 1990). The first ESSC Congress, held at Silsoe College, Bedfordshire, UK, resulted in a further review (Rickson, 1994). The second ESSC Congress, held at Munich, in September 1996, provided selected papers in a special issue of Soil and Tillage Research (1998, Volume 46, Issues 1 and 2) (Auerswald and Kutilek, 1998). The third ESSC Congress, held in Valencia, Spain, in March 2000, focused on highlighting ESSC work for public attention. It offered a timely review of the status of soil erosion and conservation research at the dawn of the new millennium, with the publication of two comprehensive Congress volumes (including 196 chapters), mainly dealing with the European dimension (Rubio et al., 2002). The fourth ESSC Congress was held in Budapest in May 2004.

An e-mail based 'soil erosion discussion group', coordinated by Purdue University, West Lafayette, IN, USA (e-mail address: se-list@ecn.purdue.edu), provides a valuable means of discussion and communication, linking over 360 subscribers world-wide (Bernsdorf and Favis-Mortlock, 1995).

Increased activity of the International Erosion Control Association (IECA) in Europe is another welcome trend. The IECA was founded in 1972 and based at Steamboat Springs, CO, USA (http://www.ieca.org/). It operates mainly in the USA, but its first European Conference was held in Barcelona in May 1996. The practical outlook of the IECA, with strong emphasis on technical, engineering and industrial solutions to erosion and sediment control, should complement and enhance the activities of more academically orientated European researchers.

Rational policies must be designed at international, national, regional and local scales. At the European scale, the European Soil Bureau (ESB) is a useful forum for discussion of Europe's soil management problems. This was initiated by meetings of the heads of Europe's soil survey organisations in 1989 and led to the establishment of the ESB in 1996, based at the EU Joint Research Centre in Ispra, Italy. The ESB focuses on harmonising soil survey operations, but could play an increasingly important role in promoting sustainable development of Europe's soil resources (http://esb.aris.sai.jrc.it/).

The EC is playing an increasingly active role in developing soil conservation strategies. The 6th Environmental Action Programme (EAP) of the European Union was adopted in 2002 and identified soil as a natural system and a non-renewable resource and established the general objective to protect soil, particularly against erosion and pollution. 
The Environment Directorate General of the EC has drafted a policy that 'contains the commitment by the Commission to develop a thematic strategy for soil with the ultimate goal of raising the political importance of soil issues at EU level, so soil protection receives adequate attention'. The 'Soil Protection Communication' (26 October 2001) passed public consultation enabling the policy statement 'Towards a Thematic Strategy for Soil Protection' to be published on 16 April 2002 (Commission of the European Communities, 2002).

The EC is developing a broad overview of soil problems in Europe. It considers erosion to be a critical problem for Europe's soils and believes that soil conservation is a cornerstone of soil protection policy. The Commission recognises that problems in southern Europe are well documented and are clearly evident in the presence of rills and gullies. However, the situation is more insidious in northern Europe. For instance, high erosion rates can occur by sheet erosion, which is usually not considered a significant problem by farmers. Furthermore, associated pollution of waterways by erosion-derived agrochemicals is largely 'invisible' and does not receive sufficient attention. The Commission takes the view that considerable data exist on the nature, extent and severity of erosion on European agricultural soils. The need for more information and monitoring of soil erosion processes, such as gully erosion, piping and soil losses associated with root and tuber harvesting and land levelling, have been identified. The need both to consider the extent and severity of soil degradation problems and to support attempts to develop suitable and innovative soil conservation measures is stressed, including the potential of conservation tillage as a soil conservation measure. There is significant concern about possible implications of the former 'Accession States' joining the EU, as many have considerable soil management problems, particularly associated with chemical contamination (Commission of the European Communities, 2002).

The EC believes that education is important to increase public awareness of soil as a resource and proposes a glossary of soil terms would be useful. The importance of soil as a store for Europe's archaeological heritage is also acknowledged.

The EC identifies areas where there is a paucity of information on Europe's soils. Relatively little is known about long-term trends in soil organic matter contents, the carbon sequestration potential of soil and the capacity of soils to safely absorb sludges. Better understanding is required of linkages between erosionderived pollution of waterways and threats to the integrity of aquatic ecosystems. There is debate on the potential effects of ecological-organic agriculture on soils, but it is generally agreed it will increase soil biodiversity. The Commission appeals for more data on soil sealing and sterilisation by construction and industrial activities. The considerable heterogeneity of Europe's soils poses problems in developing universally applicable policies. Further challenges are posed by European political diversity, with 156 political units (e.g. Lande, States, Cantons) responsible for policy implementation within the former $15 \mathrm{EU}$ states.

It is recognised that although there are some 41 international conventions dealing with the environment, only one deals with land and is specific to arid environments (UN Convention to Combat Desertification, UNCCD). The Commission is investigating national policies on soil protection (for instance, in Belgium, Denmark, France, Germany, The Netherlands, Sweden and the UK) and attempting to abstract different policy options applicable to Europe. The 'Thematic Strategy for Soil Protection' will be updated regularly, in consultation with interested parties, including the 'Stakeholders Forum' established in January 2002. This strategy is a permanent and integral component of the Commission's overall environmental and agricultural policy. The text is available at the EC web site: http://europa.eu.int/comm/environment/soil/ index.htm.

Interested members of the public can express their views on soil policy to the EC via the web-based 'CIRCA-Soil' (the soil policy electronic forum), launched in July 2003, at http://forum.europa.eu.int/Public/ irc/env/Home/main.

In spring 2003, the EC established five technical working groups with the main goals of gathering existing information on the eight identified soil threats and making recommendations for measures and policy options. 
Three soil priority areas were defined (erosion, contamination and organic matter), constituting the core issues of three thematic working groups. Further, two horizontal working groups on monitoring and research were established. The other five soil threats were dealt with by the most related working groups: compaction, floods, landslides and salinisation were linked to erosion, biodiversity was linked to organic matter and sealing by construction was linked to research. The final aim of the working groups is to contribute to EC deliverables. However, what will be delivered depends on political decisions taken by the new Commissioner, appointed in November 2004. It will be a single package, including a communication on actions, and possibly a Soil Framework Directive. The EC will also formulate directions for future research.

Generally, especially from within the Working Group on Soil Erosion, the development and implementation of a Soil Framework Directive was supported. This was in order to reach a more coherent and visible soil policy, rather than only linking up soil issues with different other policies. This would imply legally binding measures to protect soils from threats and the obligation for Member States to monitor the state and trends of soils with respect to these threats. The foundation of national and/or a European Soil Conservation Service was considered necessary for the proper implementation of such a Directive. The amendment of existing policies to address soil threats better, e.g. through the Water Framework Directive or the CAP, was also suggested. After the technical working groups finished their reports (15 May 2004), the consultation phase was finished. The future development of the EU Soil policy will then largely be determined at the political level, but at the administrative and expert level the protection of soils is acknowledged as a high-priority concern.

Governments have crucial roles to play, especially at a national level (Napier et al., 2000b). They should direct their policy to monitor the status of their national soils and to achieve proper soil use and conservation. A commendable example of a clearly formulated policy statement is the 'Sustainable Land Management Strategy' of the New Zealand Government (Ministry for the Environment of New Zealand, 1996; Bettjeman, 2000). There is debate whether government actions should be on a cooperative and voluntary basis (e.g. Johnson, 2000), or whether there should be a more coercive and regulatory approach (e.g. Napier and Napier, 2000a,b). Where possible, government involvement should not be authoritarian or punitive, but should aim at facilitating conservation by assisting in the identification of problems, in tackling the underlying causes of soil misuse and by encouraging necessary actions. A senior administrative body or commission would be necessary for such a task. The body should, in consultation with interested parties, establish, promote and finance research priorities. However, if all reasonable attempts at cooperation fail, then a more coercive approach would be necessary. Current emphasis on the 'polluter pays' principle goes some way towards addressing this issue. The responsible body should have clear and verifiable aims. For instance, the 'Ontario Land Stewardship Program' (OLSP) in Canada has been criticized for lacking specific and measurable aims (Stonehouse, 2000).

Availability of accurate, high-quality soil data is pivotal to a successful policy. A European and national inventory of land resources is necessary, so gaps in knowledge are identified and, where necessary, studies commissioned. National soil survey organisations must play a vital role in providing information (Young, 1991). Bullock and Thompson (1996) argued for a two-stage integrated policy for improving the sustainability of UK soil resources. First is the identification of the current state of soils, to assess the capability, vulnerability, sensitivity and resilience of soils, to inform the decision-making process. Second is to match soils and their use, so land use is sustainable and appropriate.

European governments have tended to regard national soil survey organisations as rather esoteric entities, and their finances are often vulnerable to the whims of finance ministries. Much can be learnt from the US experience, where the Soil Survey is a respected, properly funded organisation, with a relatively high profile in public awareness (Batie, 1985). European Soil Surveys should consider adopting the policy of US County soil surveys of incorporating USLE soil erodibility $(K)$ value assessments into their mapping at the series scale. This approach has proved useful for regional erodibility mapping in Belgium (Pauwels 
et al., 1980), Denmark (Madsen et al., 1986) and Germany (Becher et al., 1980; Jäger, 1994). In addition, temporal trends in organic content of arable soils should be closely monitored (Fullen, 1991b). The NSRI evaluated changes in soil organic matter between the early 1980s and 1995 and found that concentrations are decreasing on arable topsoils and many former peats are now classified as humose mineral soils (Bullock and Burton, 1996).

Paucity of information on the costs of erosion impedes full evaluation of its effects. Data collection and evaluation of both 'on-site' and 'off-site' costs are problematic. Many costs are difficult to quantify, borne by various groups (e.g. local councils, water authorities, insurance companies and householders), are inherently difficult to collate and are not necessarily costed as being directly due to soil erosion (Stammers and Boardman, 1984). Costing of erosion and related flooding episodes on the South Downs of England placed 'off-site' costs between $€ 90000$ and $€ 350000$ and up to almost $€ 1.8$ million at Rottingdean in 1987 (Boardman et al., 1994). A tentative costing of both 'on-site' and 'off-site' erosion in England and Wales produced a combined total of $€ 1,400$ million per year (Evans, 1995). The 'off-site' cost associated with downstream sedimentation is considered to be the dominant problem (ADAS, 2002; Boardman, 2002). Similar 'off-site', high-cost scenarios of erosion episodes have been suggested in central Belgium, including nonquantifiable social costs of stress, induced by flood damage and risk to property (Verstraeten and Poesen, 1999). Comprehensive and accurate costing of soil erosion would be helpful, both in evaluating the problem and in planning policy responses. Adoption of the 'polluter pays' principle would promote more effective conservation.

On a regional scale, skilled personnel are necessary for consultative duties. With reference to the UK, Boardman (1988, 1991) suggested the establishment of a small soil conservation unit within MAFF. Morgan and Rickson (1990) argued the Danish Land Development Service (Hedeselskabet) or the Landgraedsla Rikisins of Iceland could act as organisational models generally within Europe. Establishment of European soil conservation services, whether as distinct entities or as subdivisions of agricultural advisory services, merits discussion. Essential components of any soil conservation service should supply free information and advice to agriculturalists and interested bodies. Advisory services should also freely disseminate information to the public, particularly educational establishments. Current UK government policy of charging fees for advice from DEFR is counterproductive. It is imperative soil that conservation field demonstrations are organised, so farmers can see tangible evidence of conservation benefits. As erosion occurs on a field scale, local conservation policies are essential (Evans, 1990). Agriculturalists must be able to call freely upon the advice and expertise of soil scientists. In this respect, Europeans have much to learn from the US NRCS. Advisors should assist farmers, identifying causes of erosion and selecting appropriate technologies for remediation. Evolution of a conservation plan should be an interactive process between an advisor and agriculturalist, leading to the development of a range of possible costed strategies. Costs of remedial or preventative measures may be prohibitive, therefore the US cost-share system, where the NRCS can meet up to $75 \%$ of the cost of conservation measures, seems appropriate. A similar approach is adopted by the Icelandic SCS (Arnalds, 1999), the Canadian OLSP (Stonehouse, 2000) and by the Ministry of Flanders, Belgium (Vandekerckhove et al., 2003). With respect to US agriculture, it was argued that 'environmental credits' could be introduced to recognise and financially reward actions of producers who voluntarily introduce conservation systems on their land (Weber and Margheim, 2000). Sanders (1990) stressed the need for local voluntary organisations to discuss erosion problems. The US County soil conservation district could provide a useful model. In such a forum, interested parties meet and discuss local erosion problems and potential solutions.

Education plays an essential role in informing the public on the importance of soil as a resource. Several illustrative examples of good practice can be identified. These include the US NRCS policy to identify 'State Soils', that is, a specific soil type associated with each State. These are used in school education programmes, with students visiting representative profiles. Soil education was a major component of the EXPO 2000 
Exhibition, near Hannover, Germany, held from June to October 2000 (Auerswald, 2000; http://www. obe2000.de). In Devon, England, the Institute of Grassland and Environmental Research (IGER) has made important contributions, including the production of an educational resource leaflet for teachers and students entitled 'Working with Soil'. IGER has also developed educational 'Soil Trails', designed on the basis of 'Nature Trails'.

It is imperative that the broader benefits for soil conservation to society are recognised. Not only is conservation beneficial to agricultural development, it also assists several environmental objectives. For instance, soil conservation is compatible with habitat creation and the promotion of biodiversity. Soil conservation can assist with the accumulation of soil organic matter, which is an important 'sink' for atmospheric carbon. In turn, carbon sequestration can help ameliorate global warming (Wedin and Tilman, 1996; Arnalds, 1999; Lal, 2000).

\subsubsection{CONCLUSIONS}

The extent and severity of erosion on European soils have increased markedly over the last 50 years, particularly on arable land. However, government action and advice on soil conservation have been limited. Recently, government and agency interest in soil erosion has increased, largely owing to 'off-site' costs and problems associated with downstream sedimentation and water quality. Taking countries representative of different regions of Europe, a broad range of instruments are used, usually at the catchment scale. These include agri-environment measures, legal instruments, erosion control plans, the promotion of participatory approaches, subsidies, education programmes and the development of advisory services. These instruments are promoted to varying degrees, in response to both the severity of erosion problems and the degree of government interest and involvement. In this review of strategies to improve soil conservation, several 'best management' practices are identified. Policies at international, national, regional and local scales should include:

1. Initiation of national soil conservation services. These organisations should be properly-funded and relatively well publicised.

2. Full mapping, monitoring and costing of erosion risk by national soil survey organisations.

3. A participatory approach to soil conservation, involving farmers and interested members of the public.

4. A 'cost-share' partnership between government and farmers.

5. Development of rational land-use policies, such as targeting temporary and permanent set-aside on steep and erodible land, use of grass strips on erodible arable slopes and the protection and management of riparian zones.

6. Increased public understanding and awareness of the value of soil resources through education programmes. Education schemes should particularly encourage 'land literacy' among participants.

7. Broader benefits of effective soil conservation to society should be recognised and promoted, such as its potential contribution to habitat creation, promotion of biodiversity and carbon sequestration.

\section{REFERENCES}

ADAS, Agricultural Development and Advisory Service. 1984. Soil Erosion by Water. Ministry of Agriculture, Fisheries and Food Advisory Leaflet 890. Ministry of Agriculture, Fisheries and Food Publications, Alnwick.

ADAS, Agricultural Development and Advisory Service. 1985. Soil Erosion by Wind. Ministry of Agriculture, Fisheries and Food Advisory Leaflet 891. Ministry of Agriculture, Fisheries and Food Publications, Alnwick.

ADAS, Agricultural Development and Advisory Service. 2002. Slip sliding away. Environment News and Views. 
Adderley PW, Davidson DA, Grieve IC, Hopkins DW, Salt CA. 2001. Issues Associated with the Development of a Soil Protection Strategy for Scotland. Report prepared by the Department of Environmental Science, University of Stirling, for the Scottish Executive, Environment and Rural Affairs Department.

Als C. 1989. How to succeed in planting $900 \mathrm{~km}$ of shelterbelts per year in a small country like Denmark. In Soil Erosion Protection Measures in Europe, Schwertmann U, Rickson RJ, Auerswald K (eds). Soil Technology Series 1. Catena Verlag, Cremlingen-Destedt; 25-27.

Arnalds A. 1999. Incentives for soil conservation in Iceland. In Incentives for Soil Conservation - from Theory to Practice, Sanders DW, Huzar PC, Sombatbanit S, Enters T (eds). Oxford and IBH Publishers, New Delhi, 135-150.

Arnalds A. 2000. Evolution of rangeland conservation strategies. In Rangeland Desertification, Arnalds O, Archer S (eds). Kluwer, Dordrecht; 153-163.

Arnalds A. 2004. Carbon sequestration and the restoration of land health. Journal of Climatic Change 65: $333-346$.

Arnalds O, Barkarsson B. 2003. Soil erosion and land-use policy in Iceland in relation to sheep grazing and government subsidies. Environmental Science and Policy 6: 105-113.

Arnalds O, Thorarinsdottir EF, Metusalemsson SM, Jonsson A, Gretarsson E, Arnason A. 2001. Soil Erosion in Iceland. Soil Conservation Service and Agricultural Research Institute, Reykjavik.

Auerswald K. 2000. The fascination of soil at the EXPO 2000. Newsletter of the European Society for Soil Conservation 1/2000: $7-8$.

Auerswald K, Kutilek M. 1998. A European view of the protection of the soil resource. Soil and Tillage Research 46: ix-xi.

Bagley GR. 1979. Evolution of institutional arrangements: a nongovernmental view. In Soil Conservation Policies: an Assessment. Soil Conservation Society of America, Ankeny, IA; 33-43.

Batie S. 1985. Direction and politics of soil conservation policy in the United States. In Soil Erosion and Crop Productivity, Follett RF, Stewart BA (eds). Soil Science Society of America, Madison WI; 505-515.

Becher HH, Schafer R, Schwertmann U, Wittmann O, Schmidt F. 1980. Experiences in determining the erodibility of soils following Wischmeier in some areas in Bavaria. In Assessment of Erosion, De Boodt M, Gabriels D (eds). John Wiley \& Sons, Ltd, Chichester; 203-206.

Bernsdorf B, Favis-Mortlock D. 1995. An e-mail based soil erosion discussion list. Letter to the editor. Soil Use and Management 11:i.

Bettjeman W. 2000. Policies to promote sustainable land management in New Zealand. In Soil and Water Conservation Policies and Programs: Successes and Failures, Napier EL, Napier SM, Tvrdon J (eds). CRC Press, Boca Raton, FL; 585-595.

Bielders C, Ramelot C, Persoons E. 2003. Farmer perception of runoff and erosion and extent of flooding in the silt-loam belt of the Belgian Walloon Region. Environmental Science and Policy 6: 85-93.

Boardman J. 1988. Public policy and soil erosion in Britain. In Geomorphology in Environmental Planning, Hooke JM (ed). John Wiley \& Sons, Ltd, Chichester; 33-50.

Boardman J. 1991. The Canadian experience of soil conservation: a way forward for Britain? International Journal of Environmental Studies 37: 263-269.

Boardman J. 2002. The need for soil conservation in Britain - revisited. Area 34: 419-427.

Boardman J, Evans R. 1994. Soil erosion in Britain: a review. In Conserving Soil Resources: European Perspectives, Rickson RJ (ed.). CAB International, Wallingford; 3-12.

Boardman J, Foster IDL, Dearing JA. (eds) 1990. Soil Erosion on Agricultural Land. John Wiley \& Sons, Ltd, Chichester.

Boardman J, Ligneau L, de Roo A, Vandaele K. 1994. Flooding of property by runoff from agricultural land in northwestern Europe. Geomorphology 10: 183-196.

Boardman J, Poesen J, Evans R. 2003. Socio-economic factors in soil erosion and conservation. Environmental Science and Policy 6: 1-6.

Brade-Birks SG. 1944. Good Soil. English University Press, London; 189.

Bradsen JR. 2000. Landcare policies and programs in Australia. In Soil and Water Conservation Policies and Programs: Successes and Failures, Napier EL, Napier SM, Tvrdon J (eds). CRC Press, Boca Raton, FL; 515-533.

Bullock P, Burton RGO. 1996. Organic matter levels and trends in the soils of England and Wales. Soil Use and Management 12: $103-104$.

Bullock P, Thompson TRE. 1996. Towards a strategy for the sustainability of the soil resources of the UK. In Soils, Sustainability and the Natural Heritage, Taylor AG, Gordon JE, Usher MB (eds). HMSO, Edinburgh; 281-294. 
Campbell CA. 1995. Landcare: participative Australian approaches to inquiry and learning for sustainability. Journal of Soil and Water Conservation 50: 125-131.

Cartier S. 2002. Chronique d'un déluge annoncé. In Crise de la Colidarité Face aux Risques Naturels. Editions Grasset, Paris; 373.

Cattan A, Mermet L. 1998. Dix ans de promotion des pratiques agricoles favorables à l'environnement. In Les Politiques d'Environnement. Evaluation de la Première Génération: 1971-1995, Barraqué B, Theys J (eds). Recherches, Paris; 307-330.

Chambers BJ, Garwood TWD. 2000. Monitoring of water erosion on arable farms in England and Wales. Soil Use and Management 16: 93-99.

Clarke J (ed.). 1992. Set-aside. British Crop Protection Council Monograph No. 50. British Crop protection Council: Farnham.

Commission of the European Communities. 2002. Towards a Thematic Strategy for Soil Protection. Communication from the Commission to the Council, The European Parliament, The Economic and Social Committee and the Committee of the Regions. Brussels 16.4.2002 COM(2002), 179 final.

Curtis A, DeLacy T. 1995. Evaluating Landcare groups in Australia: how they facilitate partnerships between agencies, community groups and researchers. Journal of Soil and Water Conservation 50: 15-20.

Department of the Environment, Transport and the Regions (DETR). 2001. The Draft Soil Strategy for England - A Consultation Paper. HMSO, London.

de Roo APJ, Van Dijk PM, Ritsema CJ, Cramers NHDT, Stolte J, Oostindie K, Offermans, RJE, Kwaad, FJPM, Verzandvoort MA. 1995. Erosienormeringsonderzoek Zuid-Limburg. Ved-en Simulatiestudie. Rapport 364.1. DLO-Staring Centrum, Wageningen.

Djurhuus J., Heckrath G. 2000. Jordbearbejdningserosion. JordbrugsForskning 2: 15-17.

Dubgaard A. 2000. Landscape and nature conservation policies in Denmark. In Soil and Water Conservation Policies and Programs: Successes and Failures, Napier EL, Napier SM, Tvrdon J (eds). CRC Press, Boca Raton, FL; 253-270.

Duijsings JJHM. 1994. Soil erosion and soil conservation policy in South Limburg, The Netherlands. In Adopting Conservation on the Farm: an International Perspective on the Socioeconomics of Soil and Water Conservation, Napier TL, Cambiori SM, El-Swaify SA (eds). Soil and Water Conservation Society, Ankeny, IA; 235-243.

Durousset E. 1994. Contribution à l'étude de l'environnement au Niveau Local. Pratiques Sociales Associées à l'érosion des Sols Viticoles et aux Inondations qui en Résultent en Saône et Loire. Thèse de Doctorat de Sociologie, Université Paris X, Nanterre.

Ecoscope Applied Ecologists. 2003. Review of Agri-environmental Schemes - Monitoring Information and Research and Development Results. Final report for the Department of Environment, Food and Rural Affairs, London.

Esseks JD, Kraft SE. 1991. Land-user attitudes toward implementation of conservation compliance farm plans. Journal of Soil and Water Conservation 46: 365-370.

European Environment Agency. 2000. Down to Earth: Soil Degradation and Sustainable Development in Europe. A challenge for the 21st century. Environmental Issues Series No. 16: European Environment Agency, Copenhagen.

Evans R. 1990. Water erosion in British farmers' fields - some causes, impacts, predictions. Progress in Physical Geography 14: 199-219.

Evans R. 1995. Soil Erosion and Land-use: Towards a Sustainable Policy. Cambridge Environmental Initiative. Professional Seminar Series No. 7: Cambridge University Committee for Interdisciplinary Environmental Studies, Cambridge; 15-26.

Ewing S. 2000. Down the track from Rio: lessons from the Australian Landscape Program. In Soil and Water Conservation Policies and Programs: Successes and Failures, Napier EL, Napier SM, Tvrdon J (eds). CRC Press, Boca Raton, FL; 549-566.

Frielinghaus M. 2001. European Soil Campaign, Soil Convention and Soil Protection Act in Germany. In Multidisciplinary Approaches to Soil Conservation Strategies, Helming K (ed.). ZALF (Zentrum für Agrarlanschafts- und Landnutzungsforschung), Müncheburg; 79-84.

Fullen MA. 1991a. A comparison of runoff and erosion rates on bare and grassed loamy sand soils. Soil Use and Management 7: 136-139.

Fullen MA. 1991b. Soil organic matter and erosion processes on arable loamy sand soils in the West Midlands of England. Soil Technology 4: 19-31. 
Fullen MA. 1998. Effects of grass ley set-aside on runoff, erosion and organic matter levels in sandy soils in east Shropshire, U.K. Soil and Tillage Research 46: 41-49.

Fullen MA. 2000. Evolving perspectives, policies, and recommendations on soil erosion in the United Kingdom. In Soil and Water Conservation Policies and Programs: Successes and Failures, Napier EL, Napier SM, Tvrdon J (eds). CRC Press: Boca Raton, FL; 225-251.

Fullen MA. 2003. Soil erosion and conservation in Northern Europe. Progress in Physical Geography 27: $331-358$.

Gómez-Jover F. 1996. Dos años de forestación en tierras agrarias El Campo. Servicio de Estudios BBV. Bilbao 134: $199-214$.

Grimm M, Jones RJA, Rusco E, Montanarella L. 2002. Soil Erosion Risk in Italy Using USLE with Modified Input Factors for Erosivity and Erodibility. Joint Research Centre, Ispra.

Hannam ID. 2000. Soil conservation policies in Australia: successes, failures and requirements for ecologically sustainable policy. In Soil and Water Conservation Policies and Programs: Successes and Failures, Napier EL, Napier SM, Tvrdon J (eds). CRC Press, Boca Raton, FL; 493-514.

Heckrath G. 2000. Tillage Erosion: Current State, Future Trends and Prevention. FAIR3-CT96-1478 Project coordinated by Govers G. Annex 3. Progress Report for the Period 1 March 1999 to 29 February 2000. 1/24-24/24. Catholic University of Leuven, Leuven.

Hénin S, Gobillot T. 1950. L'érosion en France. Bulletin Technique d'Information 50: 431-433.

Hungarian State Law No. 55. 1994. About the soil. Chapter VI: Protection of the soil (58§-70§). In Complex CD Law Collection, 2003. Complex Kiadó kft., Budapest (in Hungarian).

Hurt RD. 1981. The Dust Bowl: an Agricultural and Social History. Nelson-Hall, Chicago.

Jäger S. 1994. Modelling regional soil erosion susceptibility using the Universal Soil Loss Equation and GIS. In Conserving Soil Resources: European Perspectives, Rickson RJ (ed.). CAB International, Wallingford; 161-177.

Johnson PW. 2000. The role of the Natural Resources Conservation Service in the development and implementation of soil and water conservation policies in the United States. In Soil and Water Conservation Policies and Programs: Successes and Failures, Napier EL, Napier SM, Tvrdon J (eds). CRC Press, Boca Raton, FL; 45-49.

Jones A. 1992. Set-aside: the German experience. $\operatorname{ECOS~13:~30-34.~}$

Kertész, Á. 2001. Land degradation in Hungary. In Response to Land Degradation, Bridges EM, Hannam ID, Oldeman LR, Penning de Vries FWT, Scherr SJ, Sombatpanit S (eds). Science Publishers, Enfield, NH; 140-148.

Lal R. 2000. A modest proposal for the year 2001: we can control greenhouse gases and feed the world … with proper soil management. Journal of Soil and Water Conservation 55: 429-433.

Lilin Ch. 1986. Histoire de la restauration des terrains en montagne au 19 siècle. Cah. ORSTOM, Sér. Pédol. 22: 139-145.

Madsen HB, Hasholt B, Platou SW. 1986. The development of a computerized erodibility map covering Denmark. In Soil Erosion in the European Community: Impact of Changing Agriculture, Chisci G, Morgan RPC (eds). Balkema, Rotterdam; 143-154.

MAFF, Ministry of Agriculture, Fisheries and Food. 1991. Set Aside. Advisory Leaflet PB0299. MAFF Publications, London.

MAFF, Ministry of Agriculture, Fisheries and Food. 1993. Code of Good Agricultural Practice for the Protection of Soil. MAFF Publication PB0617. MAFF Publications, London.

MAFF, Ministry of Agriculture, Fisheries and Food. 1994. Arable Area Payments 1994/95. Explanatory Guide: Part II. MAFF Publication PB1872. MAFF Publications, London.

MAFF, Ministry of Agriculture, Fisheries and Food. 1999. Controlling Soil Erosion: Advice for Preventing Erosion by Water in Lowland England. MAFF Publication PB4262. MAFF Publications: London.

Mallada L. 1890. Los Males de la Patria. Alianza Editorial, Madrid (1969 edition).

Margach L (ed.). 1993. Set-aside Roundup. The Way Ahead. Farming News, London.

Marsh J. 1987. The case for 'set-aside'. Span 30: 50-52.

Martin P, Joannon A, Souchère V, Papy F. 2004. Management of soil surface characteristics for soil and water conservation: the case of a silty loam region (Pays de Caux, France). Earth Surface Processes and Landforms 29: 1105-1115.

Ministerio de Agricultura, Pesca y Alimentación (MAPA). 2000. Hechos y Cifras del Sector Agroalimentario Español. Secretaria General Técnica. Ministerio de Agricultura, Pesca y Alimentación, Madrid.

Ministerio de Medio Ambiente (MIMAM). 2001. Plan Forestal Español. Dirección General de Conservación de la Naturaleza. Ministerio de Medio Ambiente, Madrid.

Ministry for the Environment of New Zealand. 1996. Sustainable Land Management. A Strategy for New Zealand. Ministry for the Environment, Wellington. 
Morgan RPC. 1992. Soil conservation options in the UK. Soil Use and Management 8: 176-180.

Morgan RPC, Rickson RJ. 1990. Issues on soil erosion in Europe: the need for a soil conservation policy. In Soil Erosion on Agricultural Land, Boardman J, Foster IDL, Dearing JA (eds). John Wiley \& Sons, Ltd, Chichester; 591-603.

Napier EL. 1990. The evolution of US soil-conservation policy: from voluntary adoption to coercion. In Soil Erosion on Agricultural Land, Boardman J, Foster IDL, Dearing JA (eds). John Wiley \& Sons, Ltd, Chichester; 627-644.

Napier EL, Napier SM. 2000a. Soil and water conservation policies and programs within the United States. In Soil and Water Conservation Policies and Programs: Successes and Failures, Napier EL, Napier SM, Tvrdon J (eds). CRC Press, Boca Raton, FL; 83-94.

Napier EL, Napier SM. 2000b. Future soil and water conservation policies and programs within the United States. In Soil and Water Conservation Policies and Programs: Successes and Failures, Napier EL, Napier SM, Tvrdon J (eds). CRC Press, Boca Raton, FL; 95-107.

Napier EL, Napier SM, Tvrdon J (eds). 2000a. Soil and Water Conservation Policies and Programs: Successes and Failures. CRC Press, Boca Raton, FL.

Napier EL, Napier SM, Tvrdon J. 2000b. Soil and water conservation policies and programs: successes and failures: a synthesis. In Soil and Water Conservation Policies and Programs: Successes and Failures, Napier EL, Napier SM, Tvrdon J (eds). CRC Press, Boca Raton, FL; 597-603.

Papy F, Martin P, Bruno JF. 1996. Comment réduire les risques d'érosion par les pratiques agricoles? S'adapter aux systèmes érosifs et au contexte économique. Presented at Forum Sécheresse Pollution Inondation Érosion. Poitiers Futuroscope, 29, 30 Septembre et 1 Octobre 1996.

Pauwels JM, Aelterman J, Gabriels D, Bollinne A, Rosseau P. 1980. Soil erodibility map of Belgium. In Assessment of Erosion, De Boodt M, Gabriels D (eds). John Wiley \& Sons, Ltd, Chichester; 193-201.

Puskás Á. 2002. Az Erózió észlelése és az Ellene Való Védekezés a Dombvidékeken Gazdálkodók Gyakorlatában. (Perception of erosion and its control in the practice of farmers cultivating hillslopes). MSc Thesis. University of Veszprém, Georgikon Faculty of Agriculture, Keszthely (in Hungarian).

Rickson RJ (ed.). 1994. Conserving Soil Resources: European Perspectives. CAB INternational, Wallingford.

Rojo L. 1998. Programmes of national agencies for mitigation of desertification in Spain. In Actions Taken by National Governmental and Non-governmental Organisations to Mitigate Desertification in the Mediterranean, Burke S, Thornes J (eds). European Commission, Brussels; 211-242.

Rojo L, Sanchez-Fuster MC. 1997. Red de Estaciones Experimentales de Seguimiento y Evaluación de la Erosión y la Desertificación (RESEL). Catálogo de Estaciones, 1996 Proyecto LUCDEME. Dirección General de Conservación de la Naturaleza. Ministerio de Medio Ambiente, Madrid.

Royal Commission. 1996. Report of the Royal Commission on Environmental Protection. Nineteenth Report. Sustainable Use of Soil. Report Cm 3165. Sir John Houghton (Chairman). HMSO, London.

Rubio JL, Morgan RPC, Asins S, Andreu V (eds). 2002. Man and Soil at the Third Millennium, Vols 1 and 2. Proceedings of the 3rd International Congress of the European Society for Soil Conservation. Geoforma Ediciones, Logroño.

Runolfsson S. 1978. Soil conservation in Iceland. In The Breakdown and Restoration of Ecosystems, Holdgate MW, Woodman MJ (eds). Plenum Press, New York; 231-238.

Sanders DW. 1990. New strategies for soil conservation. Journal of Soil and Water Conservation 45: 511-516.

Schnepf M. 2000. The role of private and professional organisations in the development of soil and water conservation policy. In Soil and Water Conservation Policies and Programs: Successes and Failures, Napier EL, Napier SM, Tvrdon J (eds). CRC Press, Boca Raton, FL; 77-82.

Sibbesen E, Iversen BV. 1997. Set-aside and land-use regulations with relation to surface runoff in Denmark. In Set-aside and Land-use Regulations with Relation to Surface Runoff in Finland, Denmark, Scotland, Netherlands, Belgium, France and Spain, Sibbesen E (ed.). SP Report No. 14. Danish Institute of Agricultural Sciences, Ministry of Food, Agriculture and Fisheries, Copenhagen; 14-16.

Soil Conservation Society of America. 1980. Soil Conservation Policies: an Assessment. Soil Conservation Society of America, Ankeny, IA.

Souchère V, King C, Dubreuil N, Lecomte-Morel V, Le Bissonnais Y, Chalat M. 2003. Grassland and crop trends: role of the European Union Common Agricultural Policy and consequences for runoff and soil erosion. Environmental Science and Policy 6: 7-16.

Stammers R, Boardman J. 1984. Soil erosion and flooding on downland areas. Surveyor 164: 8-11. 
Steiner FR. 1990. Soil Conservation in the United States. Policy and Planning. Johns Hopkins University Press, Baltimore, MD.

Stolte J, Ritsema CJ. 2001. Landinrichting als wapen tegen erosie. Aarde en Mens 5: 8-11.

Stolte J, Kalis F, Ritsema CJ. 2002. Erosiebestrijding in vlak Nederland. Bodem 4: 133-135.

Stonehouse DP. 2000. A critical assessment of the Ontario Land Stewardship Program. In Soil and Water Conservation Policies and Programs: Successes and Failures, Napier EL, Napier SM, Tvrdon J (eds). CRC Press, Boca Raton, FL; 191-209.

Vaisey JS, Weins EW, Wettlaufer RJ. 2000. The permanent cover program: is twice enough? In Soil and Water Conservation Policies and Programs: Successes and Failures, Napier EL, Napier SM, Tvrdon J (eds). CRC Press, Boca Raton, FL; 211-224.

Vandekerckhove L, Swerts M, Verstraeten G, Neven H, De Vrieze M. 2003. Four indicators of soil erosion as used by policy makers in Flanders. In Proceedings of the OECD Expert Meeting on Soil Erosion and Soil Biodiversity Indicators, 25-28 March, Rome, Italy; http://www.oecd.org.

Van Rompaey A, Govers G, Van Oost K, Van Muysen W, Poesen J. 2000. Bodemerosiesnelheden op landbouwpercelen in Vlaanderen. Report to the Land Division of the Ministry of the Flemish Community (in Dutch).

Várallyay G. 1989. Soil degradation processes and their control in Hungary. Land Degradation and Rehabilitation 1: $171-188$.

Veihe A, Hasholt B, Schiotz IG. 2003. Soil erosion in Denmark: processes and politics. Environmental Science and Policy 6: 37-50.

Verstraeten G, Poesen J. 1999. The nature of small-scale flooding, muddy floods and retention pond sedimentation in central Belgium. Geomorphology 29: 275-292.

Verstraeten G, Van Oost K, Van Rompaey A, Poesen J, Govers G. 2002. Evaluating an integrated approach to catchment management to reduce soil loss and sediment pollution through modelling. Soil Use and Management 18: $386-394$.

Verstraeten G, Poesen J, Govers G, Gillijns K, Van Rompaey A, Van Oost K. 2003. Integrating science, policy and farmers to reduce soil loss and sediment delivery in Flanders, Belgium. Environmental Science and Policy 6: 95-103.

Vivier M, Douyer Vivier M, Douyer C. 1985. Evolution de la géographie pastorale du Pays de Caux. Actes du Muséum de Rouen 4: 81-101.

Weber TA, Margheim GA. 2000. Conservation policy in the United States: is there a better way? In Soil and Water Conservation Policies and Programs: Successes and Failures, Napier EL, Napier SM, Tvrdon J (eds). CRC Press, Boca Raton, FL; 51-61.

Wedin DA, Tilman D. 1996. Influence of nitrogen loading and species composition on the carbon balance of grasslands. Science 274: 1720-1723.

Weingarten P, Frohberg K. 2000. Soil and water conservation policies in Germany. In Soil and Water Conservation Policies and Programs: Successes and Failures, Napier EL, Napier SM, Tvrdon J (eds). CRC Press, Boca Raton, FL; $319-341$.

Young A. 1991. Soil monitoring: a basic task for soil survey organisations. Soil Use and Management 7: 126-130. 


1
2
3
4
5
6
7
8
9
10
11
12
13
14
15
16
17
18
19
20
21
22
23
24
25
26
27
28
29
30
31
32
33
34
35
36
37
38
39
40
41
42
43
44
45
46
47

